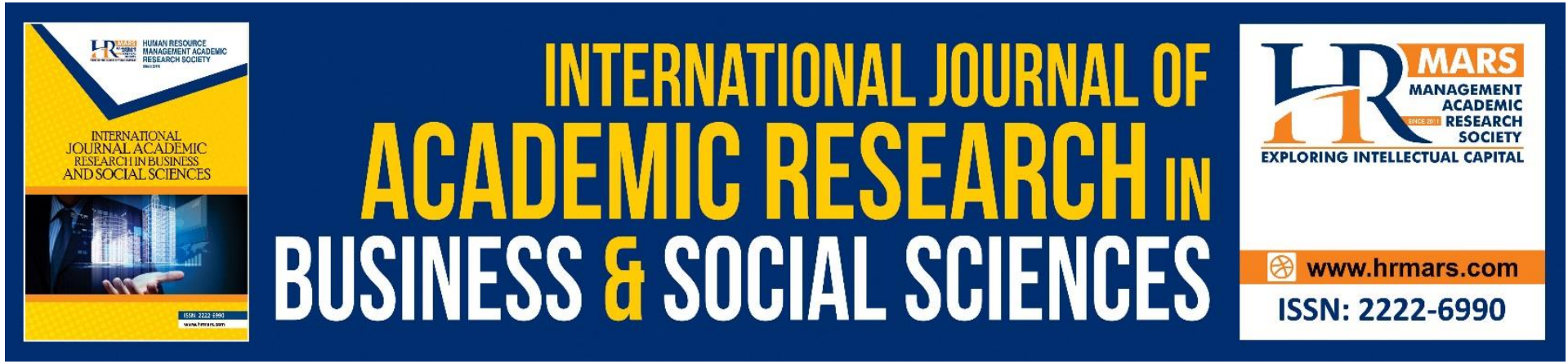

\title{
Students' Perception of Using Memory Strategies Training for Vocabulary Development
}

Nur Zarina Mohamad, Zarina Hashim, Hanis Wardah Parjan, Siti Nur Ezzah Abd Shukor, Kasturi Rajagopal, Harwati Hashim

To Link this Article: http://dx.doi.org/10.6007/IJARBSS/v11-i7/10062

DOI:10.6007/IJARBSS/v11-i7/10062

Received: 12 May 2021, Revised: 16 June 2021, Accepted: 24 June 2021

Published Online: 08 July 2021

In-Text Citation: (Mohamad et al., 2021)

To Cite this Article: Mohamad, N. Z., Hashim, Z., Parjan, H. W., Shukor, S. N. E. A., Rajagopal, K., \& Hashim, H. (2021). Students' Perception of Using Memory Strategies Training for Vocabulary Development. International Journal of Academic Research in Business and Social Sciences, 11(7), 315-328.

Copyright: (c) 2021 The Author(s)

Published by Human Resource Management Academic Research Society (www.hrmars.com)

This article is published under the Creative Commons Attribution (CC BY 4.0) license. Anyone may reproduce, distribute, translate and create derivative works of this article (for both commercial and non-commercial purposes), subject to full attribution to the original publication and authors. The full terms of this license may be seen at: http://creativecommons.org/licences/by/4.0/legalcode

Vol. 11, No. 7, 2021, Pg. 315 - 328

http://hrmars.com/index.php/pages/detail/IJARBSS

JOURNAL HOMEPAGE

Full Terms \& Conditions of access and use can be found at http://hrmars.com/index.php/pages/detail/publication-ethics 


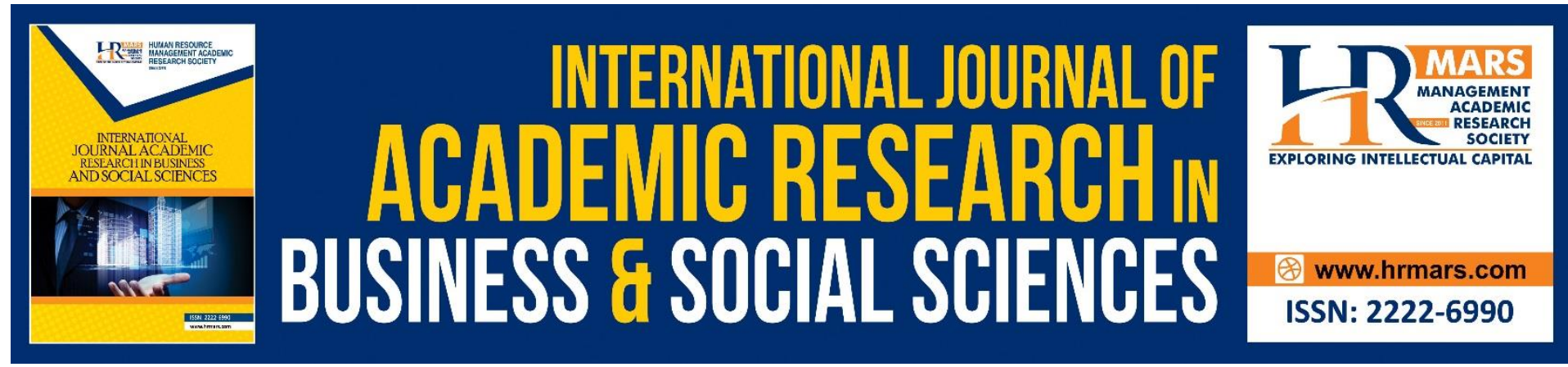

\title{
Students' Perception of Using Memory Strategies Training for Vocabulary Development
}

\author{
Nur Zarina Mohamad, Zarina Hashim, Hanis Wardah Parjan, \\ Siti Nur Ezzah Abd Shukor, Kasturi Rajagopal, Harwati Hashim \\ Faculty of Education, Universiti Kebangsaan Malaysia (UKM)
}

\begin{abstract}
English has become a necessary part of daily life in the age of globalization. The importance of English in the educational system has been recognized by people all over the world. In Malaysia, many students have achieved high language proficiency in English despite the fact that they are non-native speakers. One of the areas that need to be emphasized these days is the effective use of vocabulary in teaching primary school pupils. Thus, the aim of this study was to find out students' perception of using memory strategies training for vocabulary development to 30 Year 5 students in one of Negeri Sembilan's primary schools. This is to help them improve their vocabulary learned in English language classes from the implementation of a collection of strategies. A survey was carried out in order to assess the perception of memory strategy training on students' vocabulary growth. The results from the survey showed that students perceived the using of memory techniques as a vocabulary learning strategy in improving their vocabulary development and it is more successful than using word lists. This is based on language learning strategies for acquiring a large vocabulary and it was then used to come to a conclusion on how good language learners develop their vocabulary while studying English. The findings provided tips on how to teach English vocabulary in EFL classrooms as well as ideas about how teachers can use different strategies in the classroom. It also recommends that educators, students, policymakers, content manufacturers, and syllabus designers step away from conventional methods of vocabulary instruction and toward more creative methods.
\end{abstract}

Keywords: Language Learning Strategies, Memory Strategy Training, Vocabulary Development

\section{Introduction}

Language Learning Strategies (LLS) has been given a spotlight in improving the teaching of English language especially vocabulary in primary school children with different techniques to suit these pupils' need especially now in this $21^{\text {st }}$ Century teaching and learning. In this rapidly evolving world, 21st-century education is all about equipping students with the skills and strategies they need. Manan (2015) shows that language learners who have more control over their learning are more likely to succeed than those who don't. This is in line with Sozle (2012), who stated that the more studies that were conducted in the mid-1970s, the more important the techniques were considered to be. As we all know, apart from the four 
important skills which are Listening, Speaking, Reading and Writing, there are other components in teaching and learning English. One of them is Vocabulary. This is also agreed by Hasram \& Singh (2021), they stated that vocabulary may be thought of as the building blocks of language. Pupils with insufficient vocabulary are more likely to struggle with other facets of language and reading, writing, listening, and speaking skills are all measured by vocabulary awareness. Pupils with a limited vocabulary are more likely to have difficulty understanding verbal communication, expressing their thoughts and feelings and following written directions.

In the teaching of English language, grammar is not the only focus here. According to Panchooji \& Wasuntarasophit (2017) supported by a statement from Wilkin (1972, pp. 111112) stated that, "Little can be communicated without grammar, and nothing can be conveyed without vocabulary." This is further agreed by Abbassi et al., (2018) who mentioned that in our move to understand a language, a person's vocabulary is critical. Words are essential for communicating objects, acts, and opinions, according to Nation (2004). People would definitely fail to express their intended ideas if they do not have access to language. Morra \& Camba (2009) as cited by Abbassi et al (2018) stated that today, it is widely accepted that mastering a foreign language's vocabulary is one of the most important factors in both learning a native language and learning a foreign language. This is in accordance with Malaysian Education Blueprint (2013-2025), in one of the eleven shifts where every child is hoped to be proficient in English as well as other languages. By acquiring rich vocabulary, pupils will have more knowledge and opportunities to learn other languages as well. However, several teachers agree that vocabulary should be learned when students are studying other skills like reading and writing. (Zimmerman, 1997, as cited by Panchoojit \& Wasuntarasophit, 2017). According to Abbass et al., (2018), most language teachers have encountered situations in which one approach that works well for certain students in one class is ineffective for the rest of the class. The different learning styles have led teachers to vary their teaching methods in order to achieve the lesson objectives (Salehi \& Sadighi, 2012).

Malaysian teachers and language practitioners recognise the value of vocabulary skills in language acquisition and begin developing students' vocabulary from an early age. Despite this, previous research suggests that Malaysian ESL students have a difficult time learning new words. (Hasram \& Singh, 2021). Most educational institutions including primary schools tend to use conventional teaching approaches in which the teacher maintains power over the learning environment and exercises authority. As a result, there are thousands of nonproficient English speakers. Learning techniques, on the other hand, are primarily intended to improve communicative abilities (Oxford, 1990, as cited by Sozler, 2012). Language teachers sometimes treat vocabulary as the most difficult skill to teach since it is considered the most basic communication method (Celik \& Toptas, 2010). Even if learners are proficient in all grammatical areas of the language, they cannot communicate effectively as they lack the required expression. The use of memory strategy training on vocabulary development have been studied by many academics, writers, linguists and language teachers over the last few decades (Levenston, 1997, as cited by Sozler, 2012). Thus, the aim of this study is to find out students' perception of using memory strategies training for vocabulary development. 


\section{Research Objective}

1. To find out students' perception of using memory strategies training for vocabulary development.

\section{Literature Review \\ Language Learning Strategy \\ Definition of Language Learning Strategy}

Language learning strategies are procedures of achieving cognitive goals as in language development by language learners. Castillo et al (2014) claimed that learning strategies play important roles in language achievement and motivation which would escalate when learners regarded good results. Weinstein and Palmer (2002) defined language learning strategies as thoughts, behaviours, beliefs or emotions which facilitate learners' acquisition and understanding of new knowledge and skills of a particular language. In other terms, learning strategies are also related as cognitive or learning style of an individual. Biggs (1981) states that learning strategies as cognitive way or style of an individual that pertains the style or manner on how the individual conceptualize meanings, learning a task or solving problems in a learning task. Moreover, Griffiths (2013) describes language learning strategies as carefully chosen thoughts to deal with certain problems in language attainment in a context meanwhile Oxford (1996) explained language learning strategies as particular actions, behaviors, steps or techniques which facilitate language learning to be more autonomous and effective in new learning situations. Language learning strategies can be detained as a supporting system of a learner's academic achievement, time and effort management within an individual.

\section{Categorization Language Learning Strategies}

Oxford (2011) defined language learning strategies in six categories as memory strategies, cognitive strategies, compensation strategies, meta cognitive strategies, affective strategies and social strategies. In the classification of the strategies, memory, cognitive and compensation strategies been grouped as direct strategies whereas meta cognitive, affective and social as indirect strategies. These six strategies can be related and transferred to different tasks and learning contexts as well as it takes place in learning directly and indirectly.

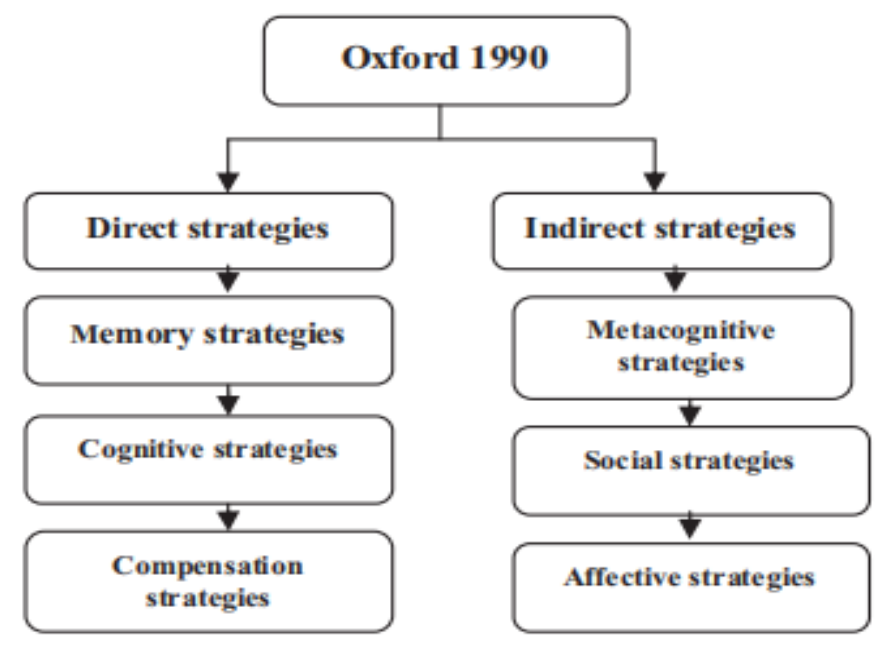

Figure 2.1.2 Taxonomy of Language Learning Strategies 


\section{Memory Strategy Training}

Memory strategy is a procedure of processing of new information in a learning context. Memory strategy is also known as an effective strategy to acquire and learn the intended vocabulary. Oxford (1990) proves that the mind can store up to trillion bits of information, but only part of that potential can be used unless memory strategies come to the aid of the learner. The memory strategy comprises four subsets, which is creating mental linkages, applying images and sound, reviewing well, and employing action. Moreover, Pressley, Levin and Miller (1981) indicated that the learners use keyword method to memorize vocabulary items in both first and second language tend to achieve better results for contextual language learning. There are different approaches and actions composed in each subset in order to promote effective learning for language learners. The use of memory strategies is pertained to be inculcated in the beginning process of language learning. This memory strategy is an effective tool to learn and remember vocabulary items for a long term.

Language learning in school involves memory strategy to store or memorize variety of information in a learning context. Learning elements such as elaboration, mental imagery, mnemonics, organization and rehearsal pretend to be important features of storing and remembering an information for long terms. According to Ornstein et al. (2009) prompted that teacher vary in how they can use memory-related language to encourage students to remember information effectively. Moreover, Oxford and Ehrman (1995) prompted that memory strategy is effective in improving subjects' proficiency for native English-speaking learners. This memory strategy is the mostly known and recommended strategy for the better classroom learning in order to acquire and learn the language in purpose.

\section{Vocabulary Development Issue among Students}

Vocabulary is an essential tool to learn to listen, speak, read and write. People would not have enough chance to communicate and express their feelings in both spoken and written without adequate vocabulary. According to Richards \& Renandya (2002), vocabulary is an essential tool for language proficiency and provides space for how learners to speak, listen, read and write. Hence, these four language skills are essential in mastering the English language. Evelyn (2008) concluded that language mastery consists of speaking, listening, reading and writing ability depends on an individual's vocabulary mastery. Vocabulary knowledge is often viewed as a milestone for second language learners to impede successful communication. In midst of learning, the learners were also encountered issues in acquiring vocabulary in better way.

As the first issue, the size of the task or assignment assigned to an individual affected the vocabulary development in a particular learning path. Hussein (2017) pointed the struggles faced by the educators in prompting learners to learn sufficient vocabulary. The lack of basic knowledge of the content of learning and time constraint made students to be dependent towards their teachers in completing the tasks assigned to them. In this case, it leads to which the language learners failed to accomplish the language task assigned in individual.

Another issue that been encountered by the language learners is the inability to adapt the difference between the spoken and written English language. Without appropriate instructional intervention of the strategy, the vocabulary gap between the more and less skillful reader getting wider by time. Mostly, the usage of vocabulary varies much in written language compared to spoken language to one another. The difference between spoken and written English cause problem to learners in line to learn English in better ways. For example, 
a conversation that occurs in a scripted drama or a movie might vary than a story that scribbled in an entitled book. If a teacher is not aware of the difference within a time, it might lead the learners in need to aid the issue of conversational fluency and proficiency with written and spoken English. Hence, to curb the issue an appropriate language learning strategy should be implemented so the learners would become a profession user of English language.

\section{Importance of Using Memory Strategy in ESL Classroom}

Language learning strategies known as deliberate approach to overcome language learning difficulties in effective ways. Memory strategy is a direct tool because it involves target language directly and explicitly. Th usage of memory strategy in ESL classroom learning, it helps learners to process the language mentally to understand and retain information. This memory strategy help learners to create linkage of information to one another and able to process the information attained for better understanding. New information that gained can be related to old information to process it and learners are enabled to increase the vocabulary store.

Moreover, this memory strategy is also important in motivating language learners to speak better. Murray (2010) showed cognitive strategy had the strongest correlation to the skill of speaking in which it is an appropriate strategy to develop their proficiency and fluency terms in language learning. Setiyadi (2010) studied that the power of this cognitive memory works to promote the skill of speaking. This study gave the benefit of practicing language through social and peer interaction. In hand with that, this memory strategy tends to motivate language learners to perceive the information attained and utilize it in order to speak fluently. Hence, this memory learning strategy plays a vital role in enhancing learner's skill to an optimum level.

\section{Good Language Learner}

In this fast-paced era, learning a second language is a challenge for language learners. An awareness about the purpose and how to learn the language is crucial. Knowing the characteristics of good language learner on how the individual pertaining the language helps to increase one's language learning proficiency. According to Sewell (2003) the desire about language learning strategies comes from a thought of knowing and understanding the characteristics of a good language learners. The proper language learning strategies plays an important role in learning process. A good language learner prompted a good display of adhering appropriate language learning strategies which would lead to an effective acquisition of a proposed language.

Apart from that, good language learners are able to perceive themselves as a risktaker. According to Brown (2000), a potential language learner is who are willing to take opportunities in their learning but not fearing to be wring in their own way. A learning will not take place unless an error occurs. By making mistakes and enable themselves to take risk based on the use of language, it enables language learners to learn the language effectively which would sustain for long terms. A good potential or having self-confidence is inter-related in which it enables learners to make mistakes in learning the desired language. It helps them converse in societal as it would be milestone for better language acquisition. Claus (2005) claimed that most researchers have denied the notion of the description on how a good language learner would portray themselves with various characteristics. They believed that 
there should not be given any limitations of how a good language learner will be as every individual have differences in their behaviours and learning style.

\section{Methodology \\ Research Design}

This study utilized a quantitative research approach. This is due to the fact that a quantitative research can help the researchers to obtain information for the research that possess questions such as what, where, how and who. Furthermore, according to Creswell (2003), quantitative research involves the inquiry techniques like experimental, surveys and other data collection tools or instruments that analyze and also produce statistical data. Besides that, the researchers of this study have a predetermined instrument to obtain numerical data to answer the research questions of investigating the effect of memory strategy training on the vocabulary development of Year 5 pupils. This research uses the survey research design. According to Ponto (2015), survey research design is often used to explains and explore the human behavior and frequently used in social and psychological researches. Since this study utilize questionnaire which is under quantitative research strategies as its main instrument, it allows the researchers to investigate the perceptions of participants towards memory strategy training on the vocabulary development as the researchers aimed to observe the changes on the participants' perception. Apart from that, survey research design can handle the outputs of a large population and relatively quick responses besides very easy to be administered whether online or face to face.

\section{Participants}

According to Noraini (2012), a population is a group of people that the researchers are interested on studying. It is the generalization which represents the bigger population. The populations usually are chosen based on the same characteristics and attributes. The sample from a population will become the source of information and data for a study. In order to carry out this study, the participants are chosen through purposive sampling. According to Merriam (2009), this type of sampling technique allows the researchers to explore, understand and retrieve perspectives from a sample in which the researchers can learn the most from. The participants of this study are Year 5 pupils in which they fulfilled the criteria that suited the aim of this study where it wants to investigate student's perception of using memory strategies training for vocabulary development. There were 30 Year 5 pupils chosen as participants. The participants' age is 11 years old and they possess basic reading skill which allow them to read independently. They also have the same level of language proficiency. According to Johanson and Christensen (2014), the criteria set will ease the process of choosing the participants with the specific characteristics among the population of interest. Furthermore, the participants aging 11 years old can utilize purposive reading apart from reading to learn (Morin, 2019). This will definitely help in the administration of data instruments in which they can answer the questions independently or with little guidance.

\section{Data Collection Tools}

In order to collect data for the student's perception of using memory strategies training for vocabulary development, a questionnaire was distributed to collect responses on students' perspective on the implementation of the memory strategy training. 


\section{Survey Questionnaire}

The questionnaire implemented was adapted from the Language Strategy Use Survey by Cohen, Oxford and Chi (2002). The inventory aimed to discover more about the language learner and to help them identify the strategies that had helped them in mastering a new language. Apart from that, this inventory is used to enhance the respondents' language learning. In this study, the researchers adapted this survey to fit the topic of research which is vocabulary knowledge. So as to suit the level of the participants, the researchers developed a questionnaire using simple sentences and vocabulary. The questionnaire has 17 questions in which they were divided into 3 sections. The first section was on the ways to learn new words with 10 questions. The second section was on the ways to remember new words with 4 questions and the last section was on the ways to use new words with 3 questions. Besides that, the questionnaire also adapted the Likert-scale in which the questions asked will use 3 points of scale which are Always, Sometimes and Never. This will be done to see the effect of the implementation of memory strategy training on the development of their vocabulary from the participants' perspective.

\section{Data Collection Procedures}

This study has 3 phases in its data collection procedures. The first phase is called introduction phase, the second phase is instructional phase and the third and last phase is distribution phase.

\section{Introduction Phase}

The first phase which is the introduction phase started with the overview and explanation of the teacher. The participants were given a briefing on the aim of the study and then the teacher proceeded to explain on the steps to implement memory strategy training and what the activity objectives. Afterwards, the participants are given time to ask any questions pertaining the explanation as to further clarify their participations during the lessons. This phase was conducted with the purpose of collecting and getting the first impression of the learning strategy of the participants.

\section{Instructional Phase}

During the second phase, the participants went through with the memory strategy training with the teacher. Participants are given sets of new vocabulary in which they are guided to create mental linkages between the sets of new vocabulary. Then, the participants are taught to place the new vocabulary into context with the help of imagery such as images or sound. Next, they participated in activities that required them to use physical responses or sensation. Lastly, they will implement mechanical techniques, for examples the use of flashcards and notepads.

\section{Distribution Phase}

In this phase, the researcher distributed the questionnaire for the participants to answer. The responses were collected and transcribed by the researcher. This was followed by the process of analyzing of data by the researchers.

\section{Data Analysis}

As for the data analysis process, the data obtained from the questionnaire will be analyzed within the aspects of validity and reliability. The data analysis began with the reorganizing of 
the raw data. For the questionnaire, the 3 points Likert-scale responses were coded with numbers during the coding procedure. Then, the data were recorded into a computerreadable format. The numerical data derived from the procedure was described using descriptive statistics and frequency distribution method. Next, all the data were presented in the form of bar charts. In order to measure the variation, the data were analyzed using percentile as to present a more comprehensive perspective for the data since it was computer-generated (Neuman, 2011). Lastly, all the information were tabulated.

\section{Findings}

\section{Questionaire}

\begin{tabular}{|l|c|c|c|c|c|c|}
\hline \multicolumn{1}{|c|}{ Items } & Always & $\%$ & Sometimes & $\%$ & Never & $\%$ \\
\hline $\begin{array}{l}\text { I pay attention to the structure of } \\
\text { a new word. }\end{array}$ & 15 & 50.0 & 10 & 33.3 & 5 & 16.7 \\
\hline $\begin{array}{l}\text { I break the word into parts that I } \\
\text { can identify. }\end{array}$ & 12 & 40.0 & 18 & 60.0 & 0 & 0 \\
\hline $\begin{array}{l}\text { I group the word into parts of } \\
\text { speech. (e.g. nouns, verbs). }\end{array}$ & 13 & 43.3 & 10 & 33.3 & 7 & 23.3 \\
\hline $\begin{array}{l}\text { I use rhyming to remember new } \\
\text { words. }\end{array}$ & 5 & 16.7 & 14 & 46.7 & 11 & 36.7 \\
\hline $\begin{array}{l}\text { I make mental image for new } \\
\text { words. }\end{array}$ & 13 & 43.3 & 10 & 33.3 & 7 & 23.3 \\
\hline $\begin{array}{l}\text { I remember related words } \\
\text { together. }\end{array}$ & 15 & 50.0 & 11 & 36.7 & 4 & 13.3 \\
\hline $\begin{array}{l}\text { I practise writing new words in } \\
\text { sentences }\end{array}$ & 8 & 26.7 & 17 & 56.7 & 5 & 16.7 \\
\hline I practice new words using action. & 8 & 26.7 & 18 & 60.0 & 4 & 13.3 \\
\hline $\begin{array}{l}\text { I use flash cards to learn new } \\
\text { words. }\end{array}$ & 13 & 43.3 & 5 & 16.7 & 12 & 40.0 \\
\hline $\begin{array}{l}\text { I relate new word with related } \\
\text { words ex: teach/teacher or } \\
\text { fish/fishermen. }\end{array}$ & 11 & 36.7 & 11 & 36.7 & 8 & 26.7 \\
\hline
\end{tabular}

Table 1. Ways to learn new words

The finding from table 1 is based on pupils' perception on ways to learn new words according to tehri preferences. Data from item 1 which is "I pay attention to the structure of a new word" shows that $15(50.0 \%)$ respondents stated they always attentive towards the structure of a new word, 10 (33.3\%) sometimes consider the words' structure and 5 (16.7\%) never give attention to the words structure of the new words. Items 2 "I break the word into parts that I can identify" result found that $12(40.0 \%)$ respondents always opted to break the word into parts that they can identify, $18(60.0 \%)$ of respondents answered "sometimes" for their inclination to break the word into identifiable parts and none of the respondent chose "never". For items "I group the word into parts of speech", 13 (43.3\%) respondents answered "always" which apply that they are able to group the new words into the respective parts of speech, $10(33.3 \%)$ chose that they "sometimes" apply this measure and 7 (23.3\%) informed that they never group the new words according to the parts of speech. Item 4 which is "I use rhyming to remember new words" gathered the responses as following $5(16.7 \%)$ 
respondents answered "always", almost half of the responses which is $14(46.7 \%)$ answered "sometimes" they apply rhyming to memorize the words while 11 (36.7\%) respondents never utilize rhyming as one of their memorization tools. For items 5 which focuses on the application of mental image, $13(43.3 \%)$ respondents opted to choose "always" which means they often opted to make mental image for new words, 10 (33.3\%) respondents stated "sometimes" while 7 (23.3\%) respondents chose "never" for items "I make mental image for new words". For items "I remember related words together". Half of the respondents 15 (50.0\%) indicated that they able to relate new words with the words that they already knew, while 11 respondents comprised $36.75 \%$ of the findings showed that they related some new words to their pre-existed vocabulary occasionally and only $4(13.3 \%)$ respondents never relate any words in their vocabulary disposition. It was found that $8(26.7 \%)$ of respondents chose "always" and more than half of the respondent 17 (56.7\%) chose "sometimes" meanwhile $5(16.7 \%)$ respondents answered "never" for items "I practise writing new words in sentences". Next, items "I practice new words using action." received responses that shows only $8(26.7 \%)$ respondents always practice new words using action, while as many as 18 $(60.0 \%)$ respondents choose "sometimes" and only a portion of the respondent 4 (13.3\%) answered "never". For items "I use flash cards to learn new words" 13 (43.3\%) respondents chose "always" and only $5(16.7 \%)$ respondents answered "sometimes" while many respondents 12 (40.0\%) opted for "never". For the last items which is "I relate new word with related words", 11 (36.7\%) respondents opted to choose "always", 11 (36.7\%) respondents stated "sometimes" while $8(26.7 \%)$ respondents chose "never".

\begin{tabular}{|l|c|c|c|c|c|c|}
\hline \multicolumn{1}{|c|}{ Items } & Always & $\%$ & Sometimes & $\%$ & Never & \% \\
\hline $\begin{array}{l}\text { I review the word often to } \\
\text { remember the word for longer } \\
\text { term. }\end{array}$ & 13 & 43.3 & 12 & 40.0 & 5 & 16.7 \\
\hline $\begin{array}{l}\text { I try to remember the situation } \\
\text { where I first heard the word or } \\
\text { saw the word. }\end{array}$ & 11 & 36.7 & 19 & 63.3 & 0 & 0 \\
\hline $\begin{array}{l}\text { I see the spelling of the new } \\
\text { words in my mind. }\end{array}$ & 13 & 43.3 & 13 & 43.3 & 4 & 13.3 \\
\hline $\begin{array}{l}\text { I find the root word of the words } \\
\text { to remember it }\end{array}$ & 4 & 13.3 & 23 & 76.7 & 3 & 10.0 \\
\hline
\end{tabular}

Table 2 ways to remember new words

From Table 2 finding, the first item for "ways to remember new words" which is "I review the word often to remember the word for longer term" received 13 (43.3\%) which encompasses of almost half of the respondent opted for "always" meanwhile another 12 $(40.0 \%)$ respondents answered "sometimes and another 5 (16.7\%) chose "never". Respondents respond on the "I try to remember the situation where I first heard the word or saw the word", 11 (36.7\%) respondents answered "always", 19 (63.3\%) respondents chose "sometimes" and none of the respondent chose "never". Next the second item which is "I see the spelling of the new words in my mind" has 13 (43.3\%) same as the number of respondents who opted for "sometime' and 4 (13.3\%) respondents answered "never". The last item "I find the root word of the words to remember it" have only 4 (13.3\%) respondent whose chose "always" while majority of the respondents 23 (76.7\%) answered "sometimes" and another $3(10 \%)$ shows that they never find the root words to memorize the words. 
INTERNATIONAL JOURNAL OF ACADEMIC RESEARCH IN BUSINESS AND SOCIAL SCIENCES Vol. 11, No. 7, 2021, E-ISSN: 2222-6990 @ 2021 HRMARS

\begin{tabular}{|l|c|c|c|c|c|c|}
\hline \multicolumn{1}{|c|}{ Items } & Always & $\%$ & Sometimes & $\%$ & Never & $\%$ \\
\hline I use new words in many ways. & 11 & 36.7 & 11 & 36.7 & 8 & 26.7 \\
\hline $\begin{array}{l}\text { I practice using familiar words in } \\
\text { different ways }\end{array}$ & 9 & 30.0 & 15 & 50.0 & 6 & 20.0 \\
\hline $\begin{array}{l}\text { I make effort to use new words in } \\
\text { my life }\end{array}$ & 13 & 43.3 & 13 & 43.3 & 4 & 13.3 \\
\hline
\end{tabular}

Table 3 ways to use new words

Table 3 reports on "ways to use new words" according to the respondent perspectives. It was found that (36.7\%) of respondents chose "always" similar with the response for sometimes meanwhile (26.7\%) respondents answered "never" for items "I use new words in many ways". Next, items "I practice using familiar words in different ways" received responses that shows only $9(30.0 \%)$ respondents always use familiar words in many ways, while as many as $15(50 \%)$ respondents choose "sometimes" and only a portion of response from $6(20 \%)$ of respondent answered "never". For the last items 13 (43.3\%) respondents chose "always same as the response for "sometimes" and only 4 (13.3\%) respondents prefer answered "never"

\section{Discussion}

\section{Pupils' Perception towards Memory Strategies}

Through the combination of multiple tools in the memory strategies training such as the manipulation and integration of images, sound and alternative ways of creating mental linkage, the finding of respondent's perspectives on the memory strategies training able to give the input to identify the most preferable tools. As stated by Chang (2015) that stress on the prominent effects of organization strategy that is recognize as a practical means in encourage learners to generate their retention even without any cognitive support by others individual such as teachers. This is because in traditional ESL language, first language learners often develop the tendency to depend on their teacher, friends or even dictionary and notes to attain the meaning and spelling of words. Though this is a good approach to learn new languages but over-dependency regularly occurs. Learners often gravitate towards obtaining supports from others even for the words or vocabulary that they have already known since it is easier to do so. However, this does not promote the learner to invest more effort to learn the words as an independent's learners. Hence, through the application of memory strategies training, the respondents show positive acceptances towards the implementation of organization strategies in memory training strategies.

Some of the respondents also agree that they always use imagery manipulation to help their vocabulary retention. This measure works best especially for visual learners since they able to remember the words better through image associations. Chang (2015) founds that by visualizing the information into a recognizable image learner able to construct a more significant mental imagery. This indicated that visual learners are motivated to use the memory strategies training as some of its components appeal to their own learning style preferences. Balini (2018) also implied that the use of imagery to learn vocabulary produce positive output for vocabulary retention.

Aside from that, auditory learners also able to benefits from the memory retention training as the evidences from the finding shows that all respondents often or sometimes incorporate the use of rhyme to develop active retention of the words in their vocabulary 
disposition. The outcome is notably similar with Balini (2018) research results that shows the positive impact of using sound to learn vocabulary. In term of the use of words dissecting strategy, finding from Nemati (2009) shows that the act of classifying language components into a more meaningful context ease the learners to remember the vocabulary better since its help highlight the important elements in the words and help decrease any discrete segments in the words. The result from Alzaidi (2017) also implied that memory strategies training help improve learners' motivation in learning new words and helps reduce anxiety during the whole vocabulary retention process. Hence, by identifying the learners' perceptions, teachers are encouraged to use to incorporate memory strategies training in teaching and learning session as it produces an overall promising outcome especially in helping learners attain, memorize and use the target vocabulary items (Balini, 2018)

Based on the final output of this intervention, the respondent's vocabulary retention skills and their positive acceptance definitely indicated a promising progress and if being continuously applied and improved, it may help motivate the learners to improve their reading and writing skills in the future. As both of these skills as closely influenced by the users' ability to accurately manipulate the words based on the given contexts.

\section{Implication}

Based on the findings above it is undeniable that each pupil has benefited and gain a positive outcome involving improvement of vocabulary list by the used of memory strategies training. It is a great outcome as they have improved a lot and has many more vocabulary list added to their previous knowledge or schemata. This happened after they used memory strategies training compared to before. Memory strategies training help these pupils by giving them list of new vocabularies and impressively includes words which are more complicated and contain six letters and above. These lists of words are from higher level of fluency as stated in CEFR standard. The intervention of memory strategies training is genuinely effective and contributes a positive reinforcement of vocabulary retention for these pupils and hopefully will help the others too.

In order to be able to tackle a language, it is important to learn the vocabulary first as the resources of words to use and to comprehend. During the early stage of learning, memory strategies training is helpful in order to build basic knowledge and collecting new list of words to support the next step of learning. Thus vocabulary retention is crucial at this stage. The implication of memory strategies training also work as a support for different types of learners such as visual learners and cater their needs during the process of learning the target language. As a whole, memory strategies training can be defined as one way to push pupils to enhance the process of vocabulary retention as to pursue their ability, talent and interest towards the target language.

\section{Conclusion}

To conclude, this study hopefully will be another milestone and become an additional guidance for this field of study while motivate the others to dig deeper on the related topic as well help many educators out there in finding ways to educate their pupils in a different but interesting way. Most pupils nowadays require a lesson which is meaningful yet fulfilling and knowledgeable to be able to focus and give their best in class. An interactive learning and the implementation of memory strategies training will be an aid to pupils while discovering the new target language. 


\section{References}

Abbassi, A., Hassaskhah, J., \& Tahriri, A. (2018). The effect of teaching memory strategies on Iranian EFL learner's vocabulary retention in terms of learners' multiple intelligences. International Journal of Education \& Literacy Studies ISSN: 2202-9478

Alzaidi, G. F. (2018). The effect of memory strategy training on vocabulary learning by EFL female students of the college of languages and translation: an experimental study.

Baliani, M. A. I., \& Jeyabalan. (2018). Role of memory strategy training in language learning. Bodhi International Journal of Research in Humanities, Arts and Science. 3-4 39-42

Biggs, J. B. (1981). The process of learning. Victoria: Prentice Hall.

Brown, H. D. (2000). Principles of language learning and teaching (4th.Ed.) White Plains, New York:Pearson Education.

Castillo, M., \& Cordora, K. (2014). Language learning strategies and academic success: A Mexican perspective. Universities Psychological. 13(2), 706-713.

Chang, S. H. (2015). Memory Strategies Used by Teachers. Online Submission.

Creswell, J. W. (2009). Research design: qualitative, quantitative and mixed methods approaches. Thousand Oaks: SAGE Publications.

Evelyn Rientje Elsjelyn. (2008). English made easy. Jakarta: Kesain Blanc.

Griffiths, C. (2013). The strategy factor in successful language learning. Bristol, U.K.: Multilingual Matters.

Gu, P. Y. (2018). Validation of an online questionnaire of vocabulary learning strategies for ESL learners. Studies in Second Language Learning and Teaching 8 (2): 325-350.

Hasram, S., \& Singh, B. K. A. (2021). Vocabulary learning strategies of good language learners from an international school. Scientific Research Journal (SCIRJ), Volume IX, Issue II, February 202131 ISSN 2201-2796

Hussein. (2017). Arab learners' problems in learning English language: A Teacher Perspective. Journal of Literature, Languages and Linguistics, 40, 1-6.

Manan, H. O. N. A. A. (2015). A study of language learning strategies ( LLS) used by ESL learners of an urban secondary school in Perak. In Constructing Contemporary Malaysia: Insight From Research Effort, Perak: Unit for Research and Intellect Application, UITM (2015) 1-10.

Merriam, S. B. (2009). Qualitative research: a guide to design and implementation. San Francisco: Jossey-Bass.

Morris, S. (2009). Style design notes: changing font and text options. Retrieved on May 10, 2021 from http://www.fiu.edu/ morriss/html/hcbnotes10.html

Nation, P. (2001). Learning vocabulary in another language. Cambridge:

Nemati, A. (2009). Memory vocabulary learning strategies and long-term retention. International Journal of Vocational and Technical Education, 1(2), 014-024.

Ornstein, P. A., Coffman, J. L., \& Grammer, J. K. (2009). Learning to remember. In O.A. Barbarin \& B. H. Wasil (Eds.), Handbook of child development and early education.

Oxford, R. L. (2011). Teaching and researching language learning strategies. London: Pearson

Panchoojit, P., \& Wasuntarasophit, S. (2017). Memory strategy options in collocation learning among EFL Learners. The 5th AASIC.

Ponto, J. (2015). Understanding and evaluating survey research. Journal of Advanced Practitioner 6 (2): 168-171. 
Santacruz, D. I., \& Ortega, D. M. (2018). Can Working Memory Strategies Enhance English Vocabulary Learning. https://doi.org/10.19183/how.25.2.410. HOW Vol. 25, No. 2, July/December 2018, ISSN 0120-5927. Bogotá, Colombia. Pages: 29-47

Sewell. (2003). The good language learner: second language acquisition

Sozler, S. (2012). The effect of memory strategy training on vocabulary development. Procedia Social and Behavioral Sciences $461348-1352$

Stake, R. E. (1995). The art of case research. California: SAGE Publications.

Weinstein, C. E., \& Palmer, D. R. (2002). Learning and Study Strategies Inventory (LASSI):

User's manual. Clearwater, FL: H \& H Publishing. 